Journal of Energy and
Environmental Sustainability
Journal homepage : www.jees.in

\title{
Design, development and performance evaluation of a fluidized bed paddy dryer
}

\author{
Pankaj Kalita ${ }^{1 *}$, Tanmay Jyoti Deka ${ }^{2}$, Samar Das ${ }^{1}$, Dudul Das ${ }^{1}$, Rupam Kataki ${ }^{2}$ \\ ${ }^{1}$ Centre for Energy, Indian Institute of Technology Guwahati, Guwahati-781 039, India; ${ }^{2}$ Department of Energy, Tezpur University, Sonitpur- 784 \\ 028, India
}

\section{A R T I C L E I N F O}

Received : 28 May 2018

Revised : 22 June 2018

Accepted : 05 July 2018

Keywords:

Paddy drying; Fluidized bed;

Moisture content; Inventory;

Drying time; Nutritional value

\begin{abstract}
A B S T R A C T
In this study a fluidized bed paddy dryer has been developed and its performance was investigated. The fuel used for generation of heat required for drying is wood rejects. In order to investigate the performance of the dryer, the experiments were performed at four different inventories and at three different air velocities. The locally available paddy variety "Ranjit" was used for experiments. The drying air temperature was maintained within $58-62^{\circ} \mathrm{C}$ to retain all the nutrients content. The change in nutritional values was also determined at different drying times viz. at 0,5 and 10 minutes from the start of the experiment and found to decrease with drying time as compared to the fresh sample. From the experiment it is evident that the drying rate increases with increase of air velocity and found to be optimum at an air velocity of $23.60 \mathrm{~m} / \mathrm{s}$.
\end{abstract}

\section{Introduction}

Last century has witnessed swift increase in the population of the world, this high rise in population put tremendous pressure on the food supply. The food supply has already been stressed by wastage of food during various post-harvest stages. About $33 \%$ of the total food produced for human consumption is wasted, with majority of loss in developing countries. The high relative humidity elevates the moisture content during storage in porous woven bags leads to fungal growth. Fungi that attacks insufficiently dried grains produce Mycotoxins, this harmful toxin reported to affect 4.5 billion people worldwide (Bradford et al., 2018). Drying is one of the primogenital and popular method employed for preservation of agricultural as well as other food products. It involves simultaneous heat and mass transfer i.e. removal of water or other solvents from solid, semi-solid or liquid substances by evaporation phenomenon. Drying mainly aims at reducing the moisture content from products to guarantee their preservation with a commercially acceptable range during storage and transport so as to avoid any kind of degradation in quality or appearance. Air temperature, velocity and relative humidity are the parameters which control the rate of drying and depending upon the nature of food these parameters can be varied (Sivakumar et al., 2016). As the Equilibrium Relative Humidity of food products decreases, the metabolic activity of bacteria, fungi and insects responsible for spoiling food is slowed because they require water to function (Crowe et al., 1992).
Drying is very important for the agricultural produces in humid areas (Iqbal et al., 2017). One of such product is Paddy or rice. Rice is the third largest producing crop in the world. India is one of the world's largest producers of rice with about $20 \%$ of world's rice production. According to reports 108.86 million tons of rice had been produced in 2016-2017 (Federal Research Division, 1996). Freshly harvested paddy possess Moisture Content (MC) of 20-25\% on wet basis (Oluleye et al., 2012). Drying of paddy is one of the most essential steps to be taken in the rice production process in the present scenario, but due to lack of proper drying technologies countries producing rice face a huge economic loss every year. Out of the total grain production in India an average of $10 \%$ is lost annually during post harvesting between the field and consumers (Shukla and Patil, 2018). A decrease in 1\% MC of the grain doubles its storage life (Jaiboon et al., 2009). On the other hand very low moisture content in paddy before milling increases the possibility of obtaining breaking grains which also decreases its economic value. Thus paddy after harvesting needs to be dried to a safe level with moisture content of around $12 \%$ on wet basis before storage (IRRI, 2013). Paddy drying is a highly energy intensive process and the quality of the rice is sensitive to the drying process. The most commonly adopted and naturally available drying method is the traditional sun drying. In India $70 \%$ of grains stored are sun dried (Lal and Ramam, n.d.). But the major limitation in sun drying is inability to control the operating parameters like moisture content, temperature, relative humidity etc. in paddy. Moreover time required in traditional sun drying is also high and this method depends highly on the

\footnotetext{
*Corresponding Author: pankaj.kalita@gmail.com
} 
weather condition mainly on intensity of solar radiation. Thus this traditional sun drying in most of the situation acts as an uncertain way to maintain the quality of the paddy as well as rice. With the view to eliminate the uncertainty in quality caused by the improper drying as well as to increase the economic market value of the rice, improved mechanical paddy drying methods need to be adopted. One of such mechanical paddy drying methods is fluidized bed paddy drying technology which is mainly effective for particulate and granular materials as it ensures complete mixing with uniform heat and mass transfer for all grains in the dryer, and thereby higher drying rate with shorter drying time can be achieved (Jaiboon et al., 2009). Fluidized bed technology is one of the most effective means for drying of non-porous moist solid particles. The process of drying using this fluidized bed technology is known as fluidized bed drying. Fluidization is the phenomenon of transforming solid particles into a fluid like state by suspending them in gas or liquid. When a gaseous fluid is passed through a bed of solid particulate substances, at some optimum condition the particles become suspended in the gas and they constantly mix together in the upward gas stream and the mixture behaves much like a boiling fluid. When the velocity is low, the bed remains stationary as no fluidization occurs and is known as fixed bed. Thermal energy necessary for evaporating the moisture is supplied to the particles and moisture is removed Induced draught effect is created with the aid of blower which sucks the fresh air into the drying unit. This hot air stream expands the material at certain velocity creating turbulence in the product. Thus fluidization takes place and the particles are dried. A number of studies have been reported on the fluidized bed drying process with reference to different aspects. Different studies based on experiment signifies the effect of the inlet air temperature, superficial gas velocity, minimum fluidization velocity, pressure drop, physical properties of the paddy and their size, moisture content, bed inventory ,time of drying and tempering on the drying rate and quality of the final product. Yahya et al. designed and developed a solar-assisted fluidized bed dryer integrated with biomass furnace for investigating the drying kinetics of paddy (Yahya et al., 2017). Experiments were conducted with mass flow rate of $0.125 \mathrm{~kg} / \mathrm{s}$ at two different temperature of $61^{\circ} \mathrm{C}$ and $78^{\circ} \mathrm{C}$ and drying time was observed to be 1281 and 796 seconds respectively. It was estimated that the system reduced the mass of the paddy from $12 \mathrm{~kg}$ to $11.43 \mathrm{~kg}$ by reducing the moisture content from $25 \%$ to $14 \%$ (dry basis). Soponronnarit and Prachayawarak studied the effect of operating parameters on product quality, drying capacity and energy consumption for a fluidized bed paddy dryer (Soponronnarit and Prachayawarakorn, 1994). Minimum fluidized bed velocity was obtained to be about $1.65 \mathrm{~m} / \mathrm{s}$. Experiments were performed at a temperature of $115^{\circ} \mathrm{C}$ and about $38 \%$ moisture content reduction was observed. Optimum parameters were estimated using a mathematical model. Fraction of air recycled of $80 \%$, air velocity of $4.4 \mathrm{~m} / \mathrm{s}$, bed thickness of $9.5 \mathrm{~cm}$ and specific air flow rate of $0.1 \mathrm{~kg} / \mathrm{s}-\mathrm{kg}$ dry matter was predicted. Soponronnarit et al. investigated the drying characteristics of corn using a batch fluidized bed dryer (Soponronnarit et al., 1997). They performed the drying experiments of corn from initial moisture content of $43 \%$ to a final moisture content of $22-23 \%$ dry basis using inlet hot air temperature 120 - $200{ }^{\circ} \mathrm{C}$, superficial air velocity of $2.2-4 \mathrm{~m} / \mathrm{s}$, bed depths of $4-12 \mathrm{~cm}$ and $0.5-0.9$ fraction of air recycled. Rao et al. performed an experimental study on thin layer convective air drying of paddy in a laboratory model thin layer dryer (Rao et al., 2007) . Drying air temperature of $70-150{ }^{\circ} \mathrm{C}$, air velocity of $0.5-2 \mathrm{~m} / \mathrm{s}$ and grain bed depth $5-20 \mathrm{~cm}$ was used in this study Maximum head yield, minimum specific energy and minimum drying time were found with grain bed depth 7-10 cm. Benny et al. did an experimental study of multi-pass drying of wet paddy and achieved an moisture content reduction of about 45 with drying air temperature of $50-55{ }^{\circ} \mathrm{C}$ in a drying period of 61.57 mins (Beeny and Basil, 1970). Tohidi et al. studied the energy and quality attributes for deep bed drying of paddy at various temperature velocity and relative humidity (Tohidi et al., 2017). The author reported that the drying rate increases with increasing temperature and velocity and higher levels of relative humidity led to longer drying durations. Dissanayake et al. carried out the performance evaluation of a mobile paddy dryer of one ton capacity developed for drying freshly harvested paddy at the field (Dissanayake et al., 2016). The overall thermal efficiency and average moisture reduction percentage was estimated to be $46.83 \%$ and $80 \%$ respectively with average drying time of 165 mins. The author also reported that the heat utilization factor, total heat efficiency and coefficient of performance of the dryer were reported to be $0.82,0.72$ and 0.18 respectively.

The study on the energy consumption has been investigated by many of researchers to go for drying by consuming the least possible amount of energy thereby keeping the quality of the dried paddy intake. Specific energy consumption of a thin layer paddy dryer with air velocity 0.55 $0.68 \mathrm{~m} / \mathrm{s}$ and drying air temperature $112-116^{\circ} \mathrm{C}$ was found to be 8.5 10.7 MJ/kg of water removed (Rao et al., 2007). It was reported that for a deep bed paddy dryer and minimum energy consumption is $0.37 \mathrm{kWh}$ at $80^{\circ} \mathrm{C}$ air temperature, $0.5 \mathrm{~m} / \mathrm{s}$ air velocity and $40 \%$ relative humidity (Tohidi et al., 2017). Continuous drying performance of rice was estimated by Chan et al. with a recirculating type solar dryer with pneumatic conveyor. A constant drying temperature of $50.1^{\circ} \mathrm{C}$ and relative humidity of $21.73 \%$ was maintained during the experiments. A drying efficiency of $22.4 \%$ was reported by the author with specific energy of $15.2 \mathrm{MJ}$ $\mathrm{kg}-1$ water evaporated for drying $104 \mathrm{~kg}$ of paddy in 5 hours (Chan et al., 2015). Researchers also studied the effect of various drying g parameters on the nutritional values of dried products. Sarker et al. evaluated the impact of drying temperature and air flow on quality of rice for an industrial inclined bed dryer (Sarker et al., 2015). The head yield rice yield was found to reduce by $1-4 \%$ using drying temperature of $41-42^{\circ}$ C. Dissanayake et al. reported head rice yields of freshly harvested paddy to be $73.78 \%$ drying with $60{ }^{\circ} \mathrm{C}$ air temperature for a mobile paddy dryer (Dissanayake et al., 2016). Rordprapat et al. investigated and compared physical properties of dried paddy such as starch gelatinization, head rice yield, drying rate, whiteness and percentage values of white belly using superheated steam and hot air (Rordprapat et al. 2005). The authors reported use of superheated steam to be favourable over the use of hot air for paddy drying.

In this work, a fluidized bed drying system is developed. Air required for fluidization is heated by utilizing heat of combustion of biomass in a combustor. The temperature of the fluidizing air is maintained by regulating the air supply. The design and working of the complete system is discussed in the subsequent sections. The widely available paddy variety "Ranjit" in the eastern part of India has been used in the experiments. In the study, drying rate and quality (nutritional value) are determined at various air velocities at controlled temperature and varying inventories.

\section{Methods and material}

\subsection{Description of the experimental setup}

The experimental setup shown in Figure 1, comprises of four main components, i.e. fluidized bed riser, biomass furnace, cyclone separator and blower. Table 1 presents complete description of the three major components of the setup. The heating source for the experiment is a furnace where fresh air enters the pipes (one end of the pipes are kept in ambient air and the other ends are connected to the blower inlet), takes the heat generated from burning of biomass and is then passed to the wet paddy grains at an increased speed placed inside the riser by using the blower. A (1 HP single phase 2800 RPM, 750 W, 2.7A) motorized blower has been used in this setup to provide the necessary air flow rate A variac is also used with the blower to regulate the air flow rate. The temperature of the hot air is controlled manually by adjusting the amount of biomass burning in the furnace bed. The hot air is supplied to the fluidized bed riser using the blower through the distributor plate (wire mess of $100 \mathrm{~mm}^{2}$ are with 36 square holes). The lower part of the riser is tapered to reduce the pressure drop and edge effect and to provide uniform air flow to the entire volume of wet paddy. The side exit of the riser is connected to the inlet of a cyclone separator. The bottom exit of the cyclone is kept open for grain collection and the hot air goes out through the top exit of the cyclone.

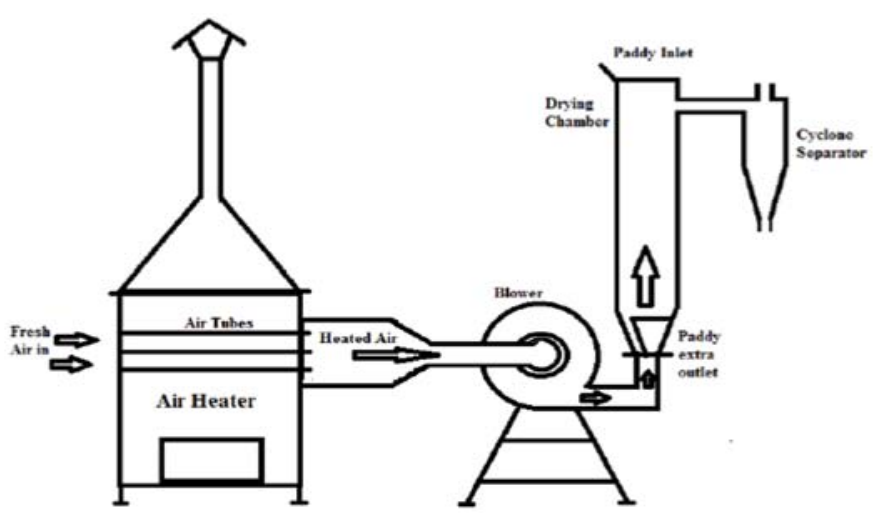

Fig.1. Schematic of the FBD Experimental set up 
Table 1 Component wise description of the set up

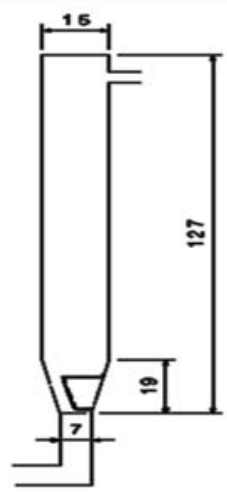

- MS sheet with a wall thickness of $1.219 \mathrm{~mm}$.

- Total length of the riser is $1270 \mathrm{~mm}$ with an internal diameter of 150 mm.

- $\quad$ Tapered conical base of $190 \mathrm{~mm}$ length with $70 \mathrm{~mm}$ diameter at lower end.

- A wire mess is used as a distributor plate for the riser with thickness 1 $\mathrm{mm}$ with 36 square holes in $100 \mathrm{~mm}^{2}$ area.
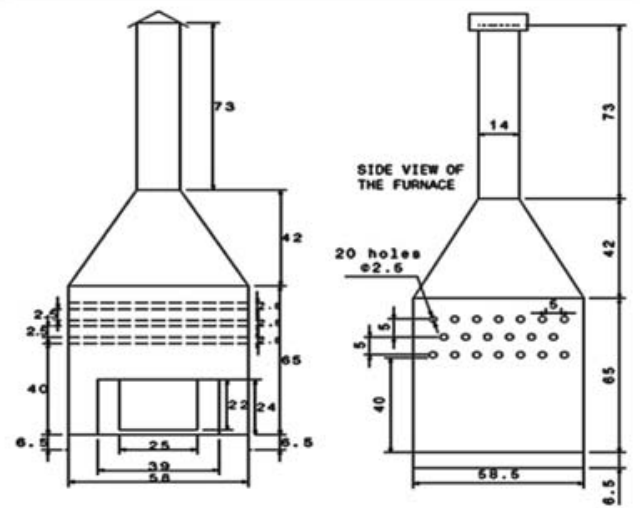

- $\quad$ The outer body of the biomass furnace is made of MS sheet of thickness $2.032 \mathrm{~mm}$.

- The rectangular base of the furnace has a length of $58.5 \mathrm{~cm}$ and width of $58 \mathrm{~cm}$.

- The total height of the biomass furnace is $180 \mathrm{~cm}$.

- 20 no's of MS pipes are arranged horizontally in three rows from end to end inside the furnace.

- A pitch of $5 \mathrm{~cm}$ between the rows is maintained.

- $\quad$ The thickness of each pipe is $2 \mathrm{~mm}$ and internal diameter is $2.5 \mathrm{~cm}$.

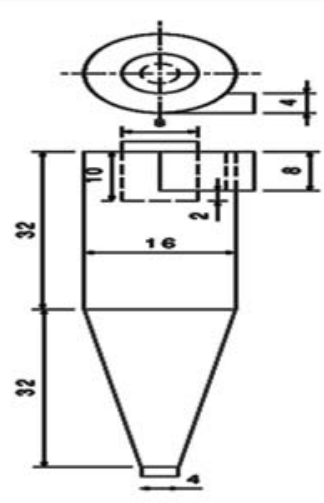

\subsection{Experimental procedure}

The study includes different experimental results evaluated by using different experimental parameters which are shown in the experimental matrix Table 2.

Table 2 Experimental Matrix

\begin{tabular}{l|l|l|l}
\hline Paddy Type & $\begin{array}{l}\text { Inventory } \\
\text { Size }\end{array}$ & $\begin{array}{l}\text { Drying Air } \\
\text { Temperature }\end{array}$ & $\begin{array}{l}\text { Drying Air } \\
\text { Velocity }\end{array}$ \\
\hline \multirow{3}{*}{ Ranjit } & $500 \mathrm{~g}$ & & $17.94 \mathrm{~m} / \mathrm{s}$ \\
& $750 \mathrm{~g}$ & $58-62^{\circ} \mathrm{C}$ & $23.60 \mathrm{~m} / \mathrm{s}$ \\
& $1000 \mathrm{~g}$ & & $26.70 \mathrm{~m} / \mathrm{s}$ \\
& $1250 \mathrm{~g}$ & & $26.70 \mathrm{~m} / \mathrm{s}$ \\
\hline
\end{tabular}

For experimental purpose a popular local variety of paddy Ranjit was selected and fresh samples were purchased from a local village in Assam, India. Ranjit is a semi tall $(105-110 \mathrm{~cm})$ variety, which was developed in Assam Agricultural University mainly to withstand flood. It is tolerant to submergence for 15 days without losing any of the traits. Ranjit is nonscented and non-glutinous variety with grains of medium slender $(27.54 \mathrm{~g} /$ 1000 grain). It has white translucent kernel having abdominal white trace. It is recommended for shallow submergence $(0-30 \mathrm{~cm}$ water depth) areas in Assam. This rice variety is photoperiod insensitive and takes 150-155 days to mature and yields 5-5.5 t/ha (ICAR NEH, 2011).

For experimentation at first a fixed amount of Ranjit paddy to be dried has been weighted in the electronic weighing balance (i.e. $500 \mathrm{~g}$, $750 \mathrm{~g}, 1000 \mathrm{~g}$ or $1250 \mathrm{~g}$ ). All the samples were rewetted by soaked in water for about 2 hours and distributed over a wire mess for about half an hour at atmospheric condition. The desired initial moisture content of rewetted paddy was about $22-24 \%$ on dry basis. The biomass furnace is pre fired for about 10- 15 minutes to get the desired temperature. Waste wood, bamboo chips and rice husk are used as fuel for the furnace. Two thermocouples (K Type) are used to measure the air temperature at the inlet and outlet. The biomass furnace is maintained to provide the required temperature (58-62 0C) during the period of drying experiment. Then initial sample has been collected to measure the initial moisture content.
The wet grains are then fed to the riser (drying chamber) through the top by opening the top door and the blower is turned on. The required air velocity for fluidization is achieved by adjusting voltage input hence power supply to the blower using a variac. Two manometers are used to measure pressure difference between paddy bed and air inlet and paddy bed and air outlet. In an interval of 5 minutes paddy samples have been collected and temperatures, pressure drop on the manometers are recorded accordingly. The experiment is performed for 30 minutes. The dried sample is then collected through the cyclone separator. After collection of the dried samples, final moisture content is measured. The moisture content of the sample is calculated using the following mathematical expression(Lahnine et al., 2016);

$$
M(t)=\frac{M_{h}(t)-M_{d}(t)}{M_{d}}
$$

where $M_{h}(t)$ is the mass of wet paddy at any time (t), similarly $M_{d}$ is the mass of dry paddy. $M_{t}(t)$ was measured at an interval of $300 \mathrm{~s}$ until a steady condition achieved. Drying of the sample was done in an oven at a temperature of $1050 \mathrm{C}$ for $24 \mathrm{~h}$. The mass difference before and after drying gives the moisture content (Lahnine et al., 2016).

Along with the moisture content of the grains it is necessary to study the nutritional value of the rice. Because excessive drying may sometime lead to decrease in the nutritional value of the rice. In this study the moisture content and nutritional value of the dried paddy has been studied and analyzed. Experiments have been conducted for determining the nutritional values by taking samples of paddy after harvesting, after 5 minutes of drying and 10 minutes of drying. In the nutritional value test mainly protein, carbohydrate, fat and fiber are determined. The methods used in determination of these nutritional values are shown in Table 3. The main apparatus used for estimating these nutritional values are FIBRA Plus Automatic Fiber Estimation System, SOCS automatic solvent/ Fat extraction system, Kjeldhal Automatic Nitrogen Distillation System, KEL PLUS automatic Macro Six Sample Digestion system, Hot air oven, Muffle furnace, Spectrophotometer, Centrifuge, Weighing scale, Heating mental etc. In the following section, experimental results along with the nutritional value obtained are discussed. 
Table 3 Test methods to determine the nutritional components of rice

\begin{tabular}{l|l}
\hline Nutritional Value Components & Test Method \\
\hline Protein & Kjeldahl Method \\
Carbohydrate & Anthrone Method \\
Fat & Soxhlet Extraction Method \\
Fiber & Crude Fiber Estimation Method \\
\hline
\end{tabular}

\section{Results and discussion}

Drying behavior of the paddy (drying rate and nutritional value) of dried paddy has been investigated for three different hot air velocities and four different inventories. The results of the experiments and observations are discussed in the following subsections.

\subsection{Moisture content and drying rate}

In this section drying behaviour of the paddy is discussed i.e. mainly the variation of moisture content at various air flow rates and inventories. Table 4 shows the variation of moisture content with time for different air velocities and inventories. Hot air temperature for drying has been maintained between $58-62{ }^{\circ} \mathrm{C}$. It has been observed from the table that for one particular inventory, with increase in air velocity, percentage reduction in moisture content increases. Drying pattern for all the experiments was observed to follow a similar trend. For air velocity of $17.94 \mathrm{~m} / \mathrm{s}$, an average reduction of $11.43 \%$ moisture content was recorded, whereas for drying velocities of $23.60 \mathrm{~m} / \mathrm{s}$ and $26.70 \mathrm{~m} / \mathrm{s}$ average moisture content were recorded to be $13.19 \%$ and $12.25 \%$ respectively. After continuous drying of 30 minutes, the final moisture content varies in the range of $9.93-9.99 \%$ at an air velocity of $17.94 \mathrm{~m} / \mathrm{s}$. Similarly for air velocities of $23.60 \mathrm{~m} / \mathrm{s}$ and $26.70 \mathrm{~m} / \mathrm{s}$, final moisture content variation was observed to be $7.72-8.86 \%$ and $7.50-8.02 \%$, respectively. It can be observed that the maximum average reduction of moisture content with air velocities of $17.94,23.60$ and $26.70 \mathrm{~m} / \mathrm{s}$ are $59.47 \%, 65.54 \%$ and $65.62 \%$ respectively. Moreover, it can also be seen that after 10 minutes of drying process, paddy moisture content for different inventories with all three velocities has been observed to be less than $14 \%$. Therefore, considering 10 minutes of drying time, moisture reduction percentage was calculated. It has been observed that for $17.94 \mathrm{~m} / \mathrm{s}$ and $26.70 \mathrm{~m} / \mathrm{s}$ of air velocities, maximum reduction of $11.99 \%$ and $13.16 \%$ was measured respectively for $500 \mathrm{~g}$ inventory, whereas for $23.60 \mathrm{~m} / \mathrm{s}$, highest value of $13.42 \%$ reduction in moisture content was observed for $1000 \mathrm{~g}$ inventory.

Figure 2 shows the variation of drying rate with respect to time at three different air velocities and at four different inventories i.e., $500 \mathrm{~g}$, $750 \mathrm{~g}, 1000 \mathrm{~g}$ and $1250 \mathrm{~g}$. It can be seen that during the initial 5 minutes, the drying rate seems to increase sharply for all four inventories and reaches a maximum value at time 5 min then it falls gradually. Similar trend has been noticed for all three air velocities. The reason of higher initial drying rate for all the experiments is mainly because of the water present in the surface of the particle which is loosely held removed most easily. The remaining water present in the particle are bound more strongly and ceased to act as if it were at a free surface which leads to sharp decrease in the drying rate. This phenomenon is called falling rate of drying(Earle, 1883). Similar kind of behaviour has been observed and it can be clearly seen in the figures that after reaching the maximum drying rate after 5 minutes, it starts decreasing and remains steady after a certain point of time. From the figure it can be seen that for all the four inventories, maximum drying rate was observed at an air velocity of $23.60 \mathrm{~m} / \mathrm{s}$. This may be due to the higher turbulence inside the riser tube causing higher heat exchange with paddy grains at $23.60 \mathrm{~m} / \mathrm{s}$ compared to $17.94 \mathrm{~m} / \mathrm{s}$ and $26.70 \mathrm{~m} / \mathrm{s}$ drying air velocities. In this study, effect of inventories has been studied by conducting experiments at fix air velocity. For a particular drying air velocity, almost same drying pattern was observed for all different inventories. The variations in the drying rate were also recorded to be very less. For inventory of $1000 \mathrm{~g}$ with air velocity of $17.94 \mathrm{~m} / \mathrm{s}$ showed maximum drying rate. With air velocities of $23.60 \mathrm{~m} / \mathrm{s}$ and $26.70 \mathrm{~m} / \mathrm{s}$ showed maximum drying rate for $500 \mathrm{~g}$ inventory. For a particular air velocity, changes in the inventory do not have any major effect on drying rate. It was observed that in case of all four inventories, falling rate was maximum for $23.60 \mathrm{~m} / \mathrm{s}$, intermediate for $26.70 \mathrm{~m} / \mathrm{s}$ and minimum for $17.94 \mathrm{~m} / \mathrm{s}$. There are various factors such as pressure drop, diffusion through the particle, change in binding energy pattern of the water molecule; heat-mass transfer from solid to ambient, which plays an important role in controlling the drying rate in the falling period and it is a complex phenomenon. Very less theoretical information are available for prediction of this region. More experimental data would be required for understanding the falling rate phenomenon in the drying process(Earle, 1883).

\begin{tabular}{|c|c|c|c|c|c|c|c|c|}
\hline \multirow{3}{*}{ 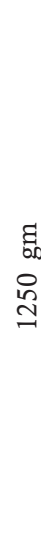 } & 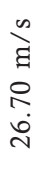 & $\begin{array}{l}n \\
0 \\
\sim \\
0 \\
+1 \\
0 \\
\stackrel{1}{0} \\
\stackrel{\sim}{v}\end{array}$ & 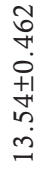 & $\begin{array}{l} \\
\Xi \\
\exists \\
0 \\
+1 \\
\text { o. } \\
a\end{array}$ & $\begin{array}{l}0 \\
\infty \\
0 \\
0 \\
+1 \\
+1 \\
\infty \\
\infty\end{array}$ & $\begin{array}{l}8 \\
8 \\
0 \\
0 \\
+1 \\
0 \\
0 \\
\infty\end{array}$ & 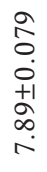 & $\begin{array}{l}0 \\
\circ \\
0 \\
+1 \\
0 \\
\text { in } \\
-1\end{array}$ \\
\hline & 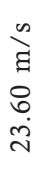 & 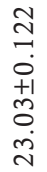 & 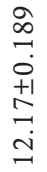 & $\begin{array}{l}- \\
\infty \\
\sim \\
0 \\
+1 \\
\infty \\
\infty \\
\infty \\
\sigma\end{array}$ & $\begin{array}{l}n \\
0 \\
m \\
0 \\
+1 \\
0 \\
0 \\
0\end{array}$ & $\begin{array}{l}0 \\
= \\
0 \\
0 \\
+1 \\
\infty \\
\infty \\
\infty\end{array}$ & 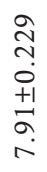 & $\begin{array}{l}2 \\
\infty \\
0 \\
0 \\
+1 \\
\stackrel{1}{N} \\
i\end{array}$ \\
\hline & 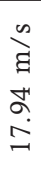 & 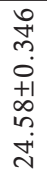 & $\begin{array}{l}0 \\
\stackrel{0}{0} \\
\sim \\
0 \\
+1 \\
n \\
0 \\
0 \\
0\end{array}$ & $\begin{array}{l}\hat{0} \\
\sim \\
0 \\
+1 \\
\stackrel{0}{0} \\
\sim \\
\stackrel{n}{n}\end{array}$ & 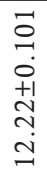 & 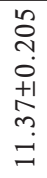 & $\begin{array}{l}0 \\
\infty \\
0 \\
0 \\
+1 \\
+1 \\
+ \\
0 \\
0\end{array}$ & $\begin{array}{l}0 \\
\exists \\
\vdots \\
+1 \\
0 \\
\circ \\
\circ\end{array}$ \\
\hline \multirow{3}{*}{$\begin{array}{l}\text { E్ } \\
\text { - } \\
8 \\
\varnothing \\
\varnothing\end{array}$} & $\begin{array}{l}\infty \\
\text { घे } \\
\stackrel{2}{N} \\
\stackrel{0}{\sim}\end{array}$ & 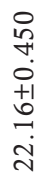 & 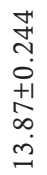 & 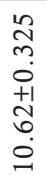 & $\begin{array}{l}\hat{0} \\
\text { a } \\
0 \\
+1 \\
\text { ஸे } \\
\text { à }\end{array}$ & 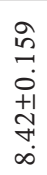 & \begin{tabular}{l}
$\stackrel{+}{S}$ \\
0 \\
$\dot{0}$ \\
+1 \\
\multirow{+}{+}{} \\
$\infty$
\end{tabular} & $\begin{array}{l}\stackrel{0}{0} \\
0 \\
0 \\
+1 \\
0 \\
\infty\end{array}$ \\
\hline & 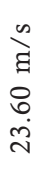 & $\begin{array}{l}\hat{o} \\
+1 \\
0 \\
+1 \\
+0 \\
-1 \\
\stackrel{+}{+}\end{array}$ & 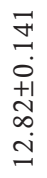 & 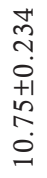 & 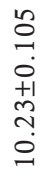 & \begin{tabular}{l}
$n$ \\
$\hat{n}$ \\
0 \\
0 \\
+1 \\
10 \\
\multirow{1}{0}{} \\
0
\end{tabular} & $\begin{array}{l}F \\
\text { F } \\
0 \\
0 \\
+1 \\
0 \\
0 \\
\infty\end{array}$ & 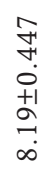 \\
\hline & 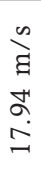 & $\begin{array}{l}\overrightarrow{0} \\
\ddot{0} \\
\dot{0} \\
+1 \\
\infty \\
\infty \\
\dot{\sim} \\
\dot{\sim}\end{array}$ & $\begin{array}{l}2 \\
\infty \\
10 \\
0 \\
+1 \\
\infty \\
\infty \\
0 \\
0\end{array}$ & 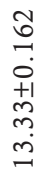 & $\begin{array}{l}m \\
m \\
0 \\
0 \\
+1 \\
n \\
m \\
\sim\end{array}$ & $\begin{array}{l}m \\
m \\
\tilde{0} \\
0 \\
+1 \\
\stackrel{+}{\sim} \\
=\end{array}$ & 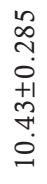 & $\begin{array}{l}0 \\
\text { In } \\
\stackrel{0}{\circ} \\
+1 \\
\text { aे } \\
\text { aे }\end{array}$ \\
\hline \multirow{3}{*}{ 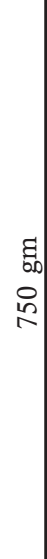 } & 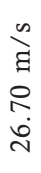 & $\begin{array}{l}\infty \\
\stackrel{\infty}{n} \\
0 \\
0 \\
+1 \\
\stackrel{1}{2} \\
\stackrel{\sim}{v}\end{array}$ & $\begin{array}{l}2 \\
2 \\
0 \\
0 \\
+1 \\
\stackrel{+}{1} \\
\stackrel{+}{J}\end{array}$ & 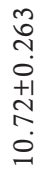 & 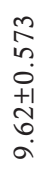 & $\begin{array}{l}m \\
2 \\
\text { d } \\
0 \\
+1 \\
\hat{N} \\
\infty\end{array}$ & $\begin{array}{l}0 \\
0 \\
0 \\
0 \\
+1 \\
\stackrel{+}{1} \\
\stackrel{\infty}{\infty}\end{array}$ & $\begin{array}{l}\text { I } \\
\stackrel{0}{\circ} \\
+1 \\
\infty \\
\infty \\
\end{array}$ \\
\hline & 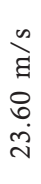 & $\begin{array}{l}8 \\
0 \\
\dot{0} \\
+1 \\
\dot{m} \\
\stackrel{N}{\sim}\end{array}$ & 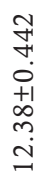 & $\begin{array}{l}0 \\
\stackrel{3}{+} \\
0 \\
+ \\
+1 \\
+ \\
\dot{0} \\
0\end{array}$ & $\begin{array}{l}\hat{0} \\
0 \\
0 \\
+1 \\
0 \\
0 \\
0\end{array}$ & $\begin{array}{l}\infty \\
\stackrel{2}{ } \\
\vdots \\
+1 \\
+\infty \\
\infty \\
\infty\end{array}$ & $\begin{array}{l}0 \\
\exists \\
\dot{0} \\
+1 \\
\stackrel{1}{1} \\
\infty\end{array}$ & $\begin{array}{l}\hat{a} \\
0 \\
0 \\
+1 \\
\hat{\alpha} \\
\end{array}$ \\
\hline & 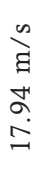 & 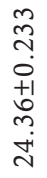 & $\begin{array}{l}\text { N } \\
\text { m } \\
0 \\
+1 \\
n \\
n \\
0 \\
0\end{array}$ & $\begin{array}{l}0 \\
\infty \\
\sim \\
0 \\
+1 \\
0 \\
0 \\
\stackrel{n}{0} \\
\sim\end{array}$ & 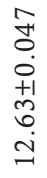 & 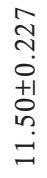 & $\begin{array}{l}\vec{n} \\
- \\
0 \\
+1 \\
+ \\
0 \\
0 \\
0\end{array}$ & 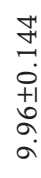 \\
\hline \multirow{3}{*}{$\begin{array}{l}\varepsilon \\
\text { 口n } \\
8 \\
\text { in }\end{array}$} & 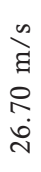 & 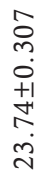 & 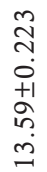 & $\begin{array}{l}\tilde{D} \\
\text { m. } \\
0 \\
+1 \\
\infty \\
0 \\
0 \\
0\end{array}$ & 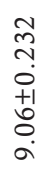 & 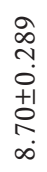 & $\begin{array}{l}\vec{\Delta} \\
\dot{0} \\
+1 \\
m \\
m \\
\infty\end{array}$ & $\begin{array}{l} \\
\infty \\
0 \\
0 \\
+1 \\
0 \\
\infty \\
0\end{array}$ \\
\hline & $\begin{array}{l}\infty \\
\text { ఏ } \\
\stackrel{0}{ } \\
\stackrel{0}{\sim} \\
\ddot{\sim}\end{array}$ & 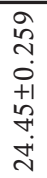 & 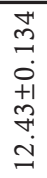 & 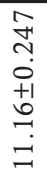 & 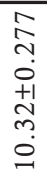 & 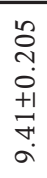 & $\begin{array}{l}\text { N } \\
\text { N } \\
\circ \\
+1 \\
\infty \\
\stackrel{+}{a}\end{array}$ & $\begin{array}{l}\tilde{D} \\
\text { N } \\
0 \\
+1 \\
0 \\
\infty \\
\infty \\
\infty\end{array}$ \\
\hline & 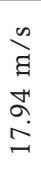 & $\begin{array}{l}\infty \\
\infty \\
n \\
0 \\
+1 \\
i n \\
n \\
\stackrel{+}{N}\end{array}$ & 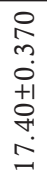 & $\begin{array}{l}0 \\
0 \\
0 \\
0 \\
+1 \\
0 \\
0 \\
\\
\end{array}$ & \begin{tabular}{l}
$\forall$ \\
0 \\
0 \\
0 \\
+1 \\
+1 \\
0 \\
0 \\
\hdashline
\end{tabular} & 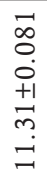 & 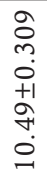 & 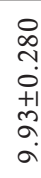 \\
\hline$\underset{\boxminus \boxminus}{\stackrel{\Xi}{G}}$ & .્ઞ્વ & 0 & in & 으 & $\stackrel{n}{n}$ & 고 & $\stackrel{2}{\sim}$ & 尺े \\
\hline
\end{tabular}



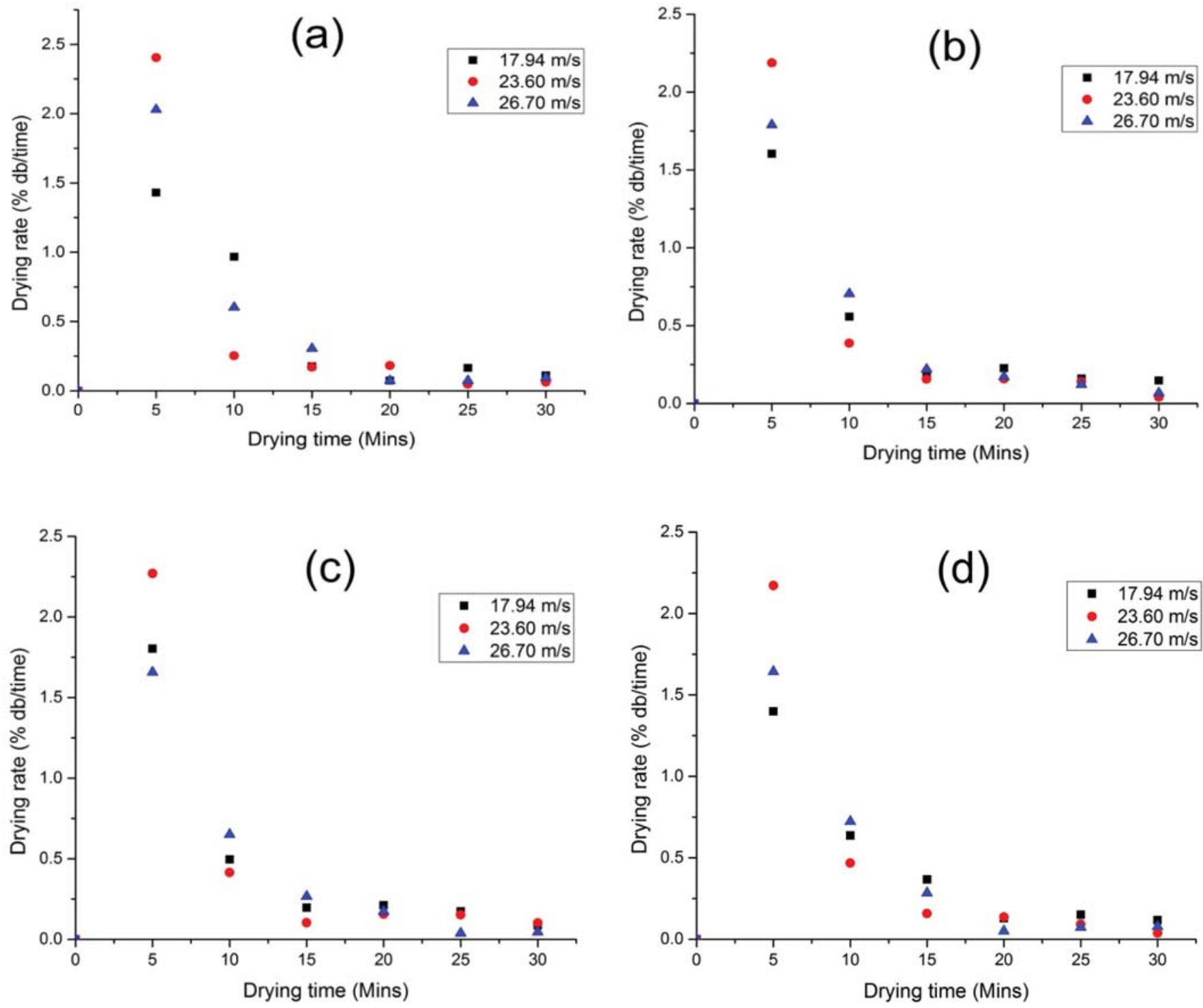

Fig.2. Effect of air velocity on drying rate for different inventories

(a) $500 \mathrm{~g}$ inventory, (b) $750 \mathrm{~g}$ inventory, (c) $1000 \mathrm{~g}$ inventory and (d) $1250 \mathrm{~g}$ inventory

\subsection{Nutritional investigation}

In the nutritional test mainly the percentage of protein, fat, fiber and carbohydrate content present in the paddy samples were determined. Nutritional content of the paddy has been tested before the drying process and after 5 and 10 minutes of drying process to obtain a comparative result. The results obtained are shown in Table 5. It has been observed from the table that nutritional values are decreasing with increase in drying time(Abbas et al., 2011; Idah et al., 2010).Heat is necessary to improve the digestibility of the crops however it decrease the macronutrient content of the grains. Application of heat results in the nutritional loss of food by causing biochemical changes (Boumendjel and Boutebba, 2003). Decrease in protein and carbohydrate content might have occurred owing to Maillard reaction. Maillard reaction is a chemical reaction between amino acids and reducing sugars that gives browned food its distinctive flavor. It has also been reported that decrease in protein content could also be caused by conversion of tannins to complexes reducing the protein availability. The $\%$ fat content gets reduced due to drying because of oxidation (Choe et al., 2001; Savage et al., 2002).

Table 6 gives a comparison of nutritional values of Ranjit variety of rice and some other Indian rice varieties. The moisture levels of all rice accessions mentioned in Table 6 varied between $8.90 \%-13.57 \%$ which is lower than the safe moisture content (14\%) for the safe storage of processed rice (Prasad et al., 2018; Verma and Srivastav, 2017). It has been observed
Table 5 Nutritional content of the three paddy samples

\begin{tabular}{l|c|c|c|c}
\hline $\begin{array}{l}\text { Sample } \\
\text { Type }\end{array}$ & $\begin{array}{c}\text { \% Crude } \\
\text { Fiber } \\
\text { content }\end{array}$ & $\begin{array}{c}\% \text { Protein } \\
\text { content }\end{array}$ & $\begin{array}{c}\% \text { Fat } \\
\text { content }\end{array}$ & $\begin{array}{c}\% \\
\text { Carbohydrate } \\
\text { content }\end{array}$ \\
\hline Normal & 2.56 & 13.84 & 2.217 & 82.64 \\
5 minutes dried & 2.09 & 12.80 & 1.65 & 77.19 \\
10 minutes dried & 1.71 & 12.01 & 1.55 & 75.055 \\
\hline
\end{tabular}

from the table that protein content is highest for Varalu variety followed by Ranjit whereas carbohydrate content is highest for Badshah Bhog rice with $82.70 \%$ followed by Sarbati.

\section{Conclusions}

The fluidized bed drying technique selected for the present study reduces drying time reasonably and also retains the nutrients of rice within the acceptable range. Some of the important findings of the current work are as follows:

- The moisture content of the paddy samples reached around 7.50-9.99 $\% \mathrm{db}$ from an initial value of $21.76-24.82 \% \mathrm{db}$ after 30 minutes of drying and reported to achieve the moisture content for safe storage (i.e. less than $14 \%$ ) within 5-10 minutes. 
Table 6 Comparison of nutritional values of various rice varieties cultivated in India

(Prasad et al., 2018; Verma and Srivastav, 2017)

\begin{tabular}{l|c|c|c|c}
\hline $\begin{array}{l}\text { Rice } \\
\text { variety }\end{array}$ & $\begin{array}{c}\% \\
\text { Fiber } \\
\text { content }\end{array}$ & $\begin{array}{c}\% \text { Protein } \\
\text { content }\end{array}$ & $\begin{array}{c}\% \text { Fat } \\
\text { content }\end{array}$ & $\begin{array}{c}\% \\
\text { Carbohydrate } \\
\text { content }\end{array}$ \\
\hline Ranjit & 1.71 & 12.01 & 1.55 & 75.055 \\
Gopal Bhog & 0.64 & 8.78 & 0.72 & 79.87 \\
Govind Bhog & 0.69 & 9.27 & 0.92 & 75.87 \\
Badshah Bhog & 0.85 & 7.23 & 0.61 & 82.70 \\
Kalanamak & 0.55 & 7.23 & 0.68 & 80.94 \\
Swetganga & 0.70 & 8.73 & 0.23 & 78.38 \\
Khusboo & 0.48 & 9.51 & 0.77 & 78.87 \\
Sarbati & 0.64 & 6.87 & 0.06 & 81.47 \\
Todal & 0.65 & 7.09 & 0.22 & 79.96 \\
DRRH-3 & 3.09 & 9.47 & 2.01 & 72.75 \\
Jaya & 3.13 & 10.11 & 1.84 & 73.33 \\
Lalat & 4.14 & 10.05 & 1.55 & 73.21 \\
NDR-97 & 4.74 & 11.57 & 2.03 & 70.09 \\
PR-113 & 3.05 & 7.63 & 1.65 & 76.41 \\
Sayasree & 4.30 & 11.25 & 1.78 & 71.57 \\
Salivahana & 2.73 & 9.84 & 1.45 & 74.85 \\
Savithri & 3.83 & 7.40 & 2.00 & 75.11 \\
TellaHamsa & 4.25 & 11.07 & 1.74 & 71.53 \\
Triguna & 3.89 & 7.64 & 1.50 & 75.68 \\
Varalu & 4.89 & 12.49 & 1.64 & 69.49 \\
\hline & & & & \\
\hline
\end{tabular}

- Drying air velocity of $23.60 \mathrm{~m} / \mathrm{s}$ was found to be optimum as the drying rate was recorded to be maximum compared to other two viz. 17.94 and $26.70 \mathrm{~m} / \mathrm{s}$.

- There was minor reduction in the nutritional values of the dried samples as compared to the moist paddy samples. The sample of 10 minutes dried sample contains $1.71 \%$ fiber, $12.01 \%$ protein, $1.55 \%$ fat and $75.055 \%$ carbohydrate.

\section{Acknowledgement}

This work is a part of project (Grant number: ASTEC/S\&T/1614(4/ 1)/2014-15/3768) awarded to Dr. Pankaj Kalita, Assistant Professor of Centre for Energy, Indian Institute of Technology, Guwahati, Assam, India by Assam Science Technology and Environment Council. The financial supported extended by Assam Science Technology and Environment Council is gratefully acknowledged.

\section{References}

[1]. Abbas, A., Murtaza, S., Aslam, F., Khawar, A., Rafique, S., Naheed, S., 2011. Effect of Processing on Nutritional Value of Rice (Oryza sativa). World J. Med. Sci., 6, 68-73.

[2]. Beeny, J.M., Basil, C.S.N., 1970. Multipass drying of paddy (rice) in the humid tropics. J. Agric. Eng. Res. 15, 364-374.

[3]. Boumendjel, M.E., Boutebba, A., 2003. Heat treatment effects on the biochemical and nutritional content of double concentrate tomato paste, in: Acta Horticulturae. International Society for Horticultural Science (ISHS), Leuven, Belgium, pp. 429432.
[4]. Bradford, K.J., Dahal, P., Van Asbrouck, J., Kunusoth, K., Bello, P., Thompson, J., Wu, F., 2018. The dry chain: Reducing postharvest losses and improving food safety in humid climates. Trends Food Sci. Technol. 71, 84-93.

[5]. Chan, Y., Dyah, T.M.N., Kamaruddin, A., 2015. Solar Dryer with Pneumatic Conveyor. Energy Procedia 65, 378-385.

[6]. Choe, E., Lee, J., Park, K., Lee, S., 2001. Effects of Heat Pretreatment on Lipid and Pigments of Freeze-Dried Spinach. Food Chem. Toxicol. 66, 1074-1079.

[7]. Crowe, J.H., Hoekstra, F.A., Crowe, L.M., 1992. Anhydrobiosis. Annu. Rev. Physiol. 54, 579-599.

[8]. Dissanayake, T.M.R., Bandara, D.M.S.P., Rathnayake, H.M.A.P., Thilakarathne, B.M.K.S., Wijerathne, D.B.T., 2016. Development of Mobile Dryer for Freshly Harvested Paddy. Procedia Food Sci. 6, 78-81.

[9]. Earle, R., 1883. Drying, URL http://www.nzifst.org.nz/unitoperations/ drying5.htm

[10]. Federal Research Division, 1996. India. Library of Congress, Washington.

[11]. Golmohammadi, M., Assar, M., Rajabi-Hamaneh, M., Hashemi, S.J., 2015.Energy efficiency investigation of intermittent paddy rice dryer: Modeling and experimental study. Food Bioprod. Process. 94, 275-283.

[12]. ICAR NEH, U., 2011. Ranjit [WWW Document]. Rice Knowl. Manag. Portal.URL http://www.rkmp.co.in/content/ranjit (accessed 5.8.18).

[13]. Idah, P.A., Musa, J.J., Olaleye, S.T., 2010. Effect of Temperature and Drying Time on Some Nutritional Quality Parameters of Dried Tomatoes. Au J. T. 14, 25-32.

[14]. Iqbal, T., Nizami, A.S., Eckhoff, S., Barreto, M.L.A., Sadef, Y., Rehan, M. Budzianowski, W.M., Ouda, O.K.M., Shahzad, K., 2017. Biomass conservationusing an optimised drying process for energy Sorghum Bagasse. Renew. EnergyFocus 19-20, 1-7.

[15]. IRRI, 2013. Paddy Drying 51.

[16]. Jaiboon, P., Prachayawarakorn, S., Devahastin, S., Soponronnarit, S., 2009.Effects of fluidized bed drying temperature and tempering time on quality of waxyrice. J. Food Eng. 95, 517-524.

[17]. Lahnine, L., Idlimam, A., Mostafa Mahrouz, Mghazli, S., Hidar, N., Hanine, H.,Koutit, A., 2016. Thermophysical characterization by solar convective drying of thyme conserved by an innovative thermal-biochemical process. Renew. Energy94, 7280 .

[18]. Lal, S., Ramam, C.P.,Grain Drying in India - Problems and Prospects.Minist. Food.

[19]. Oluleye, A. E., Ogungbemi, A.A., and Anyaeche, C.O., 2012. Designand Fabrication of a Low Cost Fluidized Bed Reactor. Innov. Syst. Des. Eng. 3,24-36.

[20]. Prasad, V.S.S., Hymavathi, A., Babu, V.R., Longvah, T., 2018. Nutritional composition in relation to glycemic potential of popular Indian rice varieties. FoodChem. 238, 29-34.

[21]. Rao, P.S., Bal, S., Goswami, T.K., 2007. Modelling and optimization of dryingvariables in thin layer drying of parboiled paddy. J. Food Eng. 78, 480-487.

[22]. Rordprapat, W., Nathakaranakule, A., Tia, W., Soponronnarit, S., 2005. Comparative study of fluidized bed paddy drying using hot air and superheatedsteam. J. Food Eng. 71, 28-36.

[23]. Sarker, M.S.H., Ibrahim, M.N., Abdul Aziz, N., Punan, M.S., 2015. Energy andexergy analysis of industrial fluidized bed drying of paddy. Energy 84, 131-138.

[24]. Savage, G.P., Dutta, P.C., Rodriguez-Estrada, M.T., 2002. Cholesterol oxides: Their occurrence and methods to prevent their generation in foods. Asia Pac. J. Clin. Nutr. 11, 72-78.

[24]. Shukla, B.D., Patil, R.T., 2018. Overview of grain drying and storage problems inIndia 3, 1-9.

[25]. Sivakumar, R., Saravanan, R., Elaya Perumal, A., Iniyan, S., 2016. Fluidized bed drying of some agro products - A review. Renew. Sustain. Energy Rev. 61, 280 301.

[26]. Soponronnarit, S., Pongtornkulpanich, A., Prachayawarakorn, S., 1997. Drying Characteristics of corn in fluidized bed dryer. Dry. Technol. 15,1603-1615.

[27]. Soponronnarit, S., Prachayawarakorn, S., 1994. Optimum strategy for Fluidized bed paddy drying. Dry. Technol. 12, 1667-1686.

[28]. Tohidi, M., Sadeghi, M., Torki-Harchegani, M., 2017. Energy and quality aspects for fixed deep bed drying of paddy. Renew. Sustain. Energy Rev. 70, 519-528.

[29]. Verma, D.K., Srivastav, P.P., 2017. Proximate Composition, Mineral Content and Fatty Acids Analyses of Aromatic and Non-Aromatic Indian Rice. Rice Sci. 24,21-31.

[30]. Yahya, M., Fudholi, A., Sopian, K., 2017. Energy and exergy analyses of solarassisted fluidized bed drying integrated with biomass furnace. Renew. Energy 105, 22-29. 